УДК 347.2

DOI https://doi.org/10.32837/pyuv.v0i1.730

Є. Ю. Поливач

orcid.org/0000-0002-4837-6870

аспірант кафедри підприємницького та корпоративного права

Київського національного економічного університету імені Вадима Гетьлана

\title{
ЗМІСТ АВТОРСЬКИХ ПРАВ НА КОМП'ЮТЕРНІ ПРОГРАМИ ТА ЇХ ВИДИ
}

Частиною 2 статті 41 Конституції України передбачено право кожного володіти, користуватися і розпоряджатися результатами своєї інтелектуальної та творчої діяльності.

Згідно з частиною 2 статті 54 Конституції, громадянам гарантується свобода літературної, художньої, наукової творчості, захист інтелектуальної власності, їхніх авторських прав, моральних і матеріальних інтересів, що виникають у зв'язку з різними видами інтелектуальної діяльності.

Кожен громадянин має право на результати своєї інтелектуальної, творчої діяльності; ніхто не може використовувати або поширювати їх без його згоди, за винятками, встановленими законом [1].

Говорячи про сучасні темпи та умови розвитку інформатизації в Україні, ми можемо бачити стрімкий розвиток світу завдяки застосуванню нових технологій, використанню можливостей комп'ютерів та взаємодії між людиною та технікою.

Тому виникає досить багато питань, які потребують вирішення на законодавчому рівні. Нині в Україні створення комп'ютерної програми прирівнюється до літературного твору [4].

Авторське право на комп'ютерні програми тісно повязано з авторським договором між творцем програми та особами, які за плату використовують твір за згодою автора, який є первинним суб'єктом авторського права [2].

Питанням правової охорони комп'ютерних програм присвячена Директива Ради ЄС про правову охорону комп'ютерних програм № 91/250/ ЄEC) від 14 травня 1991 року.

Відповідно до ст. 2 Директиви автором комп'ютерної програми є фізична особа або група осіб, які створили програму. Якщо програма створена групою осіб, то виключні права належать їм спільно. Якщо комп'ютерна програма створена працівником на виконання його обов'язків або відповідно до інструкцій, отриманих від роботодавця, то тільки роботодавець уповноважений здійснювати усі економічні права щодо такої програми, якщо інше не передбачено контрактом [6].

Розглянемо особисті немайнові права автора, які законодавець закріпив у Цивільному кодексі України.

Стаття 423 Цивільного кодексу України наводить перелік особистих немайнових прав інтелектуальної власності:
1) право на визнання людини творцем (автором, виконавцем, винахідником тощо) об'єкта права інтелектуальної власності;

2) право перешкоджати будь-якому посяганню на право інтелектуальної власності, здатному завдати шкоди честі чи репутації творця об'єкта права інтелектуальної власності;

Автору твору науки, літератури і мистецтва належать особисті немайнові права, наведені вище, а також право:

1) вимагати зазначення свого імені у зв'язку з використання твору, якщо це можливо;

2) забороняти зазначення свого імені у зв'язку з використання твору;

3) обирати псевдонім у зв'язку з використанням твору;

4) на недоторканність твору.

Особисті немайнові права часто характеризуються як невідчужувані. У частині другій статті 14 Закону України «Про авторське право і суміжні права» зазначено, що особисті немайнові права автора не можуть бути передані (відчужені) іншим особам.

Відповідно до частини другої статті 439 ЦК України у разі смерті автора недоторканність твору охороняється особою, уповноваженою на це автором. За відсутності такого уповноваження недоторканність твору охороняється спадкоємцями автора, а також іншими заінтересованими особами.

Отже, перехід до спадкоємців права на недоторканність твору і $є$ винятком із положення частини четвертої статті 423 ЦК України.

Право авторства засвідчує факт створення цього твору конкретною особою. Це право абсолютне, оскільки йому кореспондують обов'язки всіх і кожного утримуватися від порушення цієї правомочності автора.

Саме на підставі закріплених законодавством майнових прав автор може отримувати винагороду за використання своїх творів. Законом встановлено строк дії майнового права автора на протязі усього його життя і ще 70 років після його смерті, при цьому винагороду за використання твору після смерті автора можуть отримувати спадкоємці. Особисті немайнові права автора підлягають безстроковій охороні і не можуть бути відчужені [2].

Зареєстроване авторське право посвідчується Свідоцтвом, яке видає Державний департамент 
інтелектуальної власності України. Таке свідоцтво, як і немайнові права автора, не має строку дії.

Усі відносини між між співавторами творів ними можуть бути урегульовані саме договором, який є єдиним регулятором їх відносин. Як і попередній договір, його не можна віднести до якоїсь конкретної групи цивільних договорів [5].

У праві інтелектуальної власності комп'ютерні програми є об'єктами авторського права, творами у галузі науки, які охороняються як художні і літературні твори [8].

Згідно з українським законодавством, автором твору може бути виключно фзична особа. Закон говорить: «особисті немайнові права автора не можуть бути передані (відчужені) іншим особам». Таким чином, автором комп'ютерної програми буде IT-спеціаліст, який створив програму або їі частковий алгоритм.

Майнові права на комп'ютерну програму передбачають виключне право на використання, розповсюдження програми, їі копіювання, тиражування та інші дії, а також найголовніше право надання дозволу (переважно вираженого через оплатний ліцензійний договір) на усі перелічені дії.

Отже, хто ж має ці майнові права у разі, коли програміст працює на IT-компанію і розробляє на іiї замовлення певний програмний продукт?

Згідно з ч. 5 ст. 15 Закону, «за винятком випадків, передбачених статтями 21-25 Закону «Про авторське право і суміжні права», автор (чи інша особа, яка має авторське право) має право вимагати виплати винагороди за будь-яке використання твору.

Винагорода може здійснюватися у формі одноразового (паушального) платежу, або відрахувань за кожний проданий примірник чи кожне використання твору (роялті), або комбінованих платежів».

Оскільки програміст є автором програми, йому повинні були б належати майнові права на неї, незалежно від того, створив він програму загалом чи окремий її елемент.

Крім цього, ст. 31 Закону України «Про авторська право і суміжні права» передбачає, що автор (чи інша особа, яка має авторське право) може передати свої майнові права, зазначені у статті 15 вищезгаданого закону, будь-якій іншій особі повністю чи частково. Передача майнових прав автора (чи іншої особи, яка має авторське право) оформляється авторським договором.

Майнові права, що передаються за авторським договором, мають бути у ньому визначені. Майнові права, не зазначені в авторському договорі як відчужувані, вважаються такими, що не передані.

Якщо ж між сторонами немає трудових відносин, тоді сторони є самостійними субєктами господарювання. Як правило, це найбільш поширена нині схема співпраці IT-компанії з програмістами на умовах договору.

Однак далеко не всі компанії додержуються вимог ст. 31 Закону «Про авторське право і суміжні права», а саме в частині укладення з програмістом відповідного авторського договору. Зазвичай між ними укладається договір про надання послуг, договір підряду чи договір замовлення, в якому є вимоги щодо передачі майнових прав [12].

Тому, навіть зазначивши в договорах обов'язок передачі майнових прав, роботодавець - юридична особа не матиме гарантій того, що в майбутньому автор програми не заявить про недійсність такої угоди або невідповідність передачі майнових прав вимогам Закону.

У чинному законодавстві існує спеціальне поняття - «службовий твір». Якщо така комп'ютерна програма виконується програмістом під час виконання його службових обов'язків та за технічним завданням IT-компанії, тоді створена ним програма є службовим твором.

Відповідно до ст. 429 ЦК України «майнові права інтелектуальної власності на об’єкт, створений у зв'язку з виконанням трудового договору, належать працівникові, який створив цей об'єкт, та юридичній або фізичній особі, де або у якої він працює, спільно, якщо інше не встановлено договором» .

Цей висновок підтверджений i Постановою Пленуму Верховного суду України № 5 від 4.06.2010 р. «Про застосування судами норм законодавства у справах про захист авторського права і суміжних прав», де у п. 24 суд наголошує: «Якщо в трудовому або цивільно-правовому договорі між працівником і роботодавцем (юридичною або фізичною особою, де або в якої він працює) не передбачений інший порядок здійснення майнових прав на створений вказаний об’єкт, то вони мають спільні права як на отримання свідоцтва про реєстрацію авторського права на твір, так і на використання такого об'єкта. Порядок здійснення майнових прав на такий об'єкт може бути врегульований цивільно-правовим договором» [9].

У разі передання (відчуження) працівником роботодавцю всіх майнових прав на твір, створений ним у порядку виконання трудового договору, працівник втрачає ці права, залишаючись носієм особистих немайнових прав.

Виділення окремих договорів для об'єктів права інтелектуальної власності у нормах Цивільного кодексу України зумовлено, зокрема, їхньою правовою природою як результатів творчої, інтелектуальної діяльності людини, нематеріальністю та потенційною можливістю одночасного використаннярізними суб'єктами. Нематеріальний характер об’єктів права інтелектуальної власності дозволяє їх одночасне використання необмеженою кількістю осіб. 
Договори, призначені для речового права, не застосовують із метою розпоряджання майновими права інтелектуальної власності. Договори у сфері інтелектуальної власності спрямовані на розпоряджання саме майновими правами інтелектуальної власності, а не об'єктами як речами. Коли особа, якій належать майнові права на результати інтелектуальної, творчої діяльності, вступає в договірні правовідносини щодо розпоряджання майновими правами інтелектуальної власності, вона може надати іншій особі дозвіл на використання об'єкта права інтелектуальної власності чи взагалі відчужити майнові права інтелектуальної власності на користь іншої особи. Також можуть виникати правовідносини щодо створення об'єктів права інтелектуальної власності на замовлення.

Договори у сфері інтелектуальної власності досліджували такі науковці, як В.О. Бажанов, В.С. Дмитришин, О.В. Жилінкова, І.Ф. Коваль, А.О. Кодинець, О.С. Яворська, I.Є. Якубівський та інші, проте багато питань залишаються дискусійними та неврегульованими в законодавстві [12].

Правоволоділецьмайнових прав інтелектуальної власності зобов'язаний повідомити набувача таких прав про ліцензійні договори, укладені правоволодільцем з іншими особами щодо об'єктів права інтелектуальної власності, які передаються набувачу.

Зокрема, якщо на час укладення договору про відчуження майнових прав інтелектуальної власності правоволоділець уклав раніше ліцензійний договір, за яким надано виключну ліцензію, набувач зобов'язується не використовувати майнові права інтелектуальної власності та не надавати іншим особам дозвіл на використання об'єкта права інтелектуальної власності на час дії такого ліцензійного договору [5].

Якщо йдеться про відчуження майнового права на винаходи, корисні моделі, ноу-хау, то особа, яка передає майнові права інтелектуальної власності, зобов'язана навчити набувача прав використовувати такий результат, передати йому відповідну технічну документацію. Інакше особа, яка набула майнових прав інтелектуальної власності, не зможе використовувати результат. Обидві сторони мають дотримуватись умов конфіденційності, зокрема не розголошувати суть технічного результату. Набувач майнових прав інтелектуальної власності зобов'язаний дотримуватись особистих немайнових прав автора, зокрема вказувати його ім'я в разі використання об'єкта права інтелектуальної власності [5].

Беззаперечною перевагою захисту комп'ютерної програми автора через інститут комерційної таємниці є те, що такий спосіб охорони - єдиний серед усіх розглянутих, який не передбачає повного розкриття інформації третім особам.
До того ж такий механізм не потребує офіційної реєстрації, значних додаткових витрат правовласника та може бути реалізований у короткий строк.

Водночас значним недоліком в українських реаліях є недосконалість механізму практичного захисту порушених прав на комерційну таємницю та відшкодування завданих правовласнику збитків.

Найбільш доцільним рішенням для правовласника, на мій погляд, $є$ комплексний підхід до охорони та захисту своїх прав на комп'ютерні програми.

Застосування одночасно різних інститутів права інтелектуальної власності не суперечить чинному законодавству України, підсилює рівень захищеності та дає більше можливостей для відновлення порушених прав і притягнення порушника до відповідальності [11].

Авторське право на комп'ютерну програму виникає внаслідок самого факту ії створення і не потребує реєстрації, спеціального оформлення чи дотримання будь-яких інших формальностей [2].

Первинним суб'єктом, якому належить авторське право, є автор комп'ютерної програми, тобто фізична особа, яка своєю творчою працею створила програму і якій належать особисті немайнові та майнові права на цю програму. Крім того, суб'єктами авторського права можуть бути інші фізичні та юридичні особи, які набули права на комп'ютерну програму відповідно до договору або Закону.

Майновими правами інтелектуальної власності на комп'ютерну програму є право на використання твору, що згідно зі статтею 441 Цивільного кодексу України включає права на опублікування, відтворення та інші. Зазначені права можуть бути передані повністю або частково іншій особі на умовах, визначених договором щодо розпоряджання майновими правами інтелектуальної власності.

Розпоряджання майновими правами інтелектуальної власності на комп'ютерну програму відповідно до статті 1107 Цивільного кодексу України здійснюється на підставі: ліцензії на використання об’єкта права інтелектуальної власності; ліцензійного договору; договору про створення за замовленням і використання об'єкта права інтелектуальної власності; договору про передання виключних майнових прав інтелектуальної власності; іншого договору щодо розпоряджання майновими правами інтелектуальної власності [7].

\section{Jimepamypa}

1. Конституція України : офіц.текст. Київ : KM, $2013.96 \mathrm{c}$.

2. Цивільний кодекс України / Відомості Верховної Ради України, 2003, №№ 40-44, 356 с.

3. Закон України «Про авторське право і суміжні права» № 3792-XII від 23.12.1993p. / Відомості Верховної Ради України (ВВР), 1994, № 13, 64 с. 
4. Олена Стовба. «Компютерні програми таїх реєстраціï: Бути чи не бути ?» URL : https://biz.ligazakon. net/analitycs/195871 kompyutern-programi-ta-khrestrats-buti-chi-ne-buti.

5. Дмитренко В.В. Договори у сфері інтелектуальної власності за законодавством України. «Izdevnieciba «Baltija Publishing», м. Рига, Латвія. С. 150-169.

6. ІТ право / за заг. ред. проф. О.С. Яворської. Видавництво «Левада», м. Львів, 2017. С. 470.

7. Дмитришин B.С. Лист Державного Департаменту інтелектуальної власності від 16.05.2005 N 16-09/2127 URL : https://zakon.rada.gov.ua/rada/ show/v2127585-05\#Text.

8. Бернська конвенція про охорону літературних i художніх творів. URL: https://zakon.rada.gov.ua/ laws/show/995 051.

9. Постанова Пленуму Верховного суду України № 5 від 4.06.2010 р. «Про застосування судами норм законодавства у справах про захист авторського права і суміжних прав» URL : https://zakon.rada.gov.ua/laws/ show/v0005700-10\#Text.

10. Компютерні програми, «Бухгалтерський тиждень», вересень 2017/ № 38, URL: https://i.factor.ua/ ukr/journals/bn/2017/september/issue-38/ article-30559.html.

11. Наталія Грушевська. Правова охорона комп'ютерних програм: як правовласнику захистити свої права ? URL : https://is.gd/z9nrVn.

12. Авторське право на компютерну програму «Barristers and prime grouop» URL : https://is.gd/ AHEzED.

\section{Анотація}

Поливач С.Ю. Зміст авторських прав на компютерні програми та їх види. - Стаття.

Стаття присвячена висвітленню однієї з актуальних проблем сучасного становища у сфері використання, розпорядження авторськими правами на комп'ютерні програми та програмне забезпечення, які є необхідними у цифрову епоху. Одним із найбільш поширених способів використання творів є їх опублікування (випуск твору у світ).

Згідно зі ст 420 Цивільного кодексу України, комп'ютерні програми належать до об'єктів права інтелектуальної власності.

При цьому розрізняють особисті немайнові і майнові права інтелектуальної власності. Особисті немайнові права належать автору і не можуть бути передані (відчужені) іншим особам, за винятками, встановленими законом [3].

Що стосується майнових прав на об'єкт авторського права, то вони можуть бути передані (відчужені) третім особам [3].

До числа майнових прав належать: право на використання об'єкта права інтелектуальної власності, виключне право дозволяти використання об'єкта права інтелектуальної власності, виключне право перешкоджати неправомірному використанню об'єкта права інтелектуальної власності, у тому числі забороняти таке використання, інші майнові права інтелектуальної власності, встановлені законом.

Такі права набуває одержувач комп'ютерної програми в тих випадках, коли програма розробляється за його особистим замовленням або підприємство виконує подібну розробку самостійно. Крім того, майнові права інтелектуальної власності можуть бути передані їх власником повністю або частково іншій особі [2].
Доволі часто авторські права на використання комп'ютерної програми використовуються неправомірно, зокрема роботодавцями.

Відносини між автором творів та іншими особами щодо передачі майнових прав на використання твору здійсюються на підставі авторського договору.

Авторський договір є ключовим механізмом у відносинах щодо розпорядження авторськими правами на твір та захищає права автора від неправомірного використання його твору будь-якими особами.

Особливостями авторського договору на використаня комп'ютерної програми є передача майнових прав автора іншій особі для подальшого розповсюдження та використання з метою отримання автором винагороди.

Ключові слова: інтелектуальна власність; авторське право на комп’ютерну програму; авторський договір; цифрове середовище; розпорядження майновими правами інтелектуальної власності; автор; майнові права на твір.

\section{Summary}

Polyvach Ye. Yu. Contents of copyrights to computer programs and their types. - Article.

The article is devoted to one of the current problems of the current situation in the field of use, copyright management of computer programs and software, which are currently needed in the digital age. One of the most common ways to use works is to publish them (release the work into the world).

According to Article 420 of the Civil Code of Ukraine, computer programs belong to the objects of intellectual property rights. There are personal intangible and intellectual property rights. Personal non-property rights belong to the author and cannot be transferred (alienated) to other persons, except as provided by law.

As for property rights to the object of copyright, they can be transferred (alienated) to third parties.

Property rights include: the right to use the object of intellectual property rights, the exclusive right to allow the use of the object of intellectual property rights, the exclusive right to prevent the misuse of the object of intellectual property rights, including prohibiting such use, other intellectual property rights property established by law.

Such rights are acquired by the recipient of a computer program in cases where the program is developed on his personal order or the company performs such development independently. In addition, intellectual property rights may be transferred by their owner in whole or in part to another person. It is not uncommon for copyright to use a computer program to be misused, in particular by employers.

The relationship between the author of the works on the transfer of property rights to use the work is carried out on the basis of the copyright agreement.

The copyright agreement is a key mechanism in the relationship regarding the disposal of copyright to the work and protects the rights of the author from the improper use of his work by any person.

The peculiarities of the copyright agreement for the use of a computer program are the transfer of the author's property rights to another person for further distribution and use in order to receive remuneration by the author.

Key words: intellectual property; computer program copyright; copyright agreement; digital environment; disposal of intellectual property rights; author; property rights to the work. 